\title{
Hypercalcaemia in extremely low birthweight infants
}

\author{
A J LYON, N McINTOSH, K WHEELER, AND O G BROOKE \\ Department of Child Health, St George's Hospital Medical School, London
}

SUMMARY We report 10 cases of hypercalcaemia associated with hypophosphataemia in the first two weeks of life in extremely low birthweight infants (birthweight less than $1000 \mathrm{~g}$ ). At the time of diagnosis, the infants were fed mainly with expressed breast milk but they had also received intravenous nutrition. After treatment with additional phosphate plasma calcium concentrations returned to normal. There was a high incidence of rickets of prematurity in these infants.

There is dispute as to whether rickets of prematurity is due to poor absorption or metabolism of vitamin $\mathrm{D}$ or to substrate deficiency. ${ }^{12}$ There is increasing evidence that preterm infants have, at least initially, a deficient intake of calcium ${ }^{3}$ and phosphorus ${ }^{4} 5$ compared with the intrauterine accumulation. This may be a major aetiological factor in the high incidence of rickets in these babies. ${ }^{6}$ The incidence is greater than $50 \%$ in babies less than $1000 \mathrm{~g}$ at this hospital, ${ }^{2}$ despite an intake of $2000 \mathrm{U}$ of vitamin D daily from day 7 of life.

In 1983 we identified 10 extremely low birthweight infants with sustained hypercalcaemia and hypophosphataemia. We are not aware that this has been reported before. Increasing the dietary phosphate intake led to both improvement in the hypophosphataemia and return of the plasma calcium concentration to normal.

We suggest that the extreme hypophosphataemia at this time leads to mobilisation of both phosphate and calcium from bone, and that this active demineralisation plays an important part in the high incidence of rickets of prematurity in this group of infants.

\section{Patients and methods}

Infants. Thirty eight infants of birthweight less than
$1000 \mathrm{~g}$ were admitted to the neonatal unit at this hospital in 1983: 27 survived longer than one week. In all these infants serial blood samples were taken for routine monitoring; plasma calcium and phosphate concentrations were measured using standard laboratory autoanalyser methods at least every two to three days. In one infant the changes in urinary excretion of calcium and phosphorus with an alteration in phosphate intake were also measured. Careful records were kept of nutrient intakes in all infants. Wrist radiographs were performed on the infants at regular intervals, from 28 days' postnatal age.

Feeding. The unit policy is to feed infants of extremely low birthweight with expressed breast milk (fresh from their own mothers or pasteurised if from donors), supplemented as necessary with intravenous nutrition. Calcium supplements were given in the first three days of life only to treat the expected initial hypocalcaemia in these infants. Table 1 shows the calcium and phosphorus content of the intravenous solutions and the content of expressed milk. ${ }^{78}$

\section{Results}

Ten of the 27 surviving infants had a rising plasma

Table 1 Feeding regimen for extremely low birthweight infants. Any deficit from maximum enteral volume is supplied (after the 5th day) parenterally in the proportions shown

\begin{tabular}{|c|c|c|c|}
\hline & $\begin{array}{l}\text { Maximum volume } \\
\text { (ml/kg/day) }\end{array}$ & $\begin{array}{l}\text { Calcium } \\
\text { (mmol/kg/day) }\end{array}$ & $\begin{array}{l}\text { Phosphorus } \\
\text { (mmol/kg)day) }\end{array}$ \\
\hline $\begin{array}{l}\text { Expressed breast milk } \\
\text { Parenteral nutrition* }\end{array}$ & $180-200$ & $1 \cdot 2-1 \cdot 4$ & $0 \cdot 8-0 \cdot 9$ \\
\hline Solution I & 145 & $0 \cdot 84$ & $0 \cdot 36$ \\
\hline Solution II & 35 & - & 0.53 \\
\hline
\end{tabular}

*Standard solutions prepared in pharmacy: solution I - amino acids, minerals, vitamins, dextrose; solution II - intralipid, fat soluble vitamins. Conversion-SI to traditional units: phosphorus $1 \mathrm{mmol} / \mathrm{kg} /$ day $\approx 30 \cdot 9 \mathrm{mg} / \mathrm{kg} /$ day; calcium $1 \mathrm{mmol} / \mathrm{kg} / \mathrm{day} \approx 40 \mathrm{mg} / \mathrm{kg} / \mathrm{day}$. 


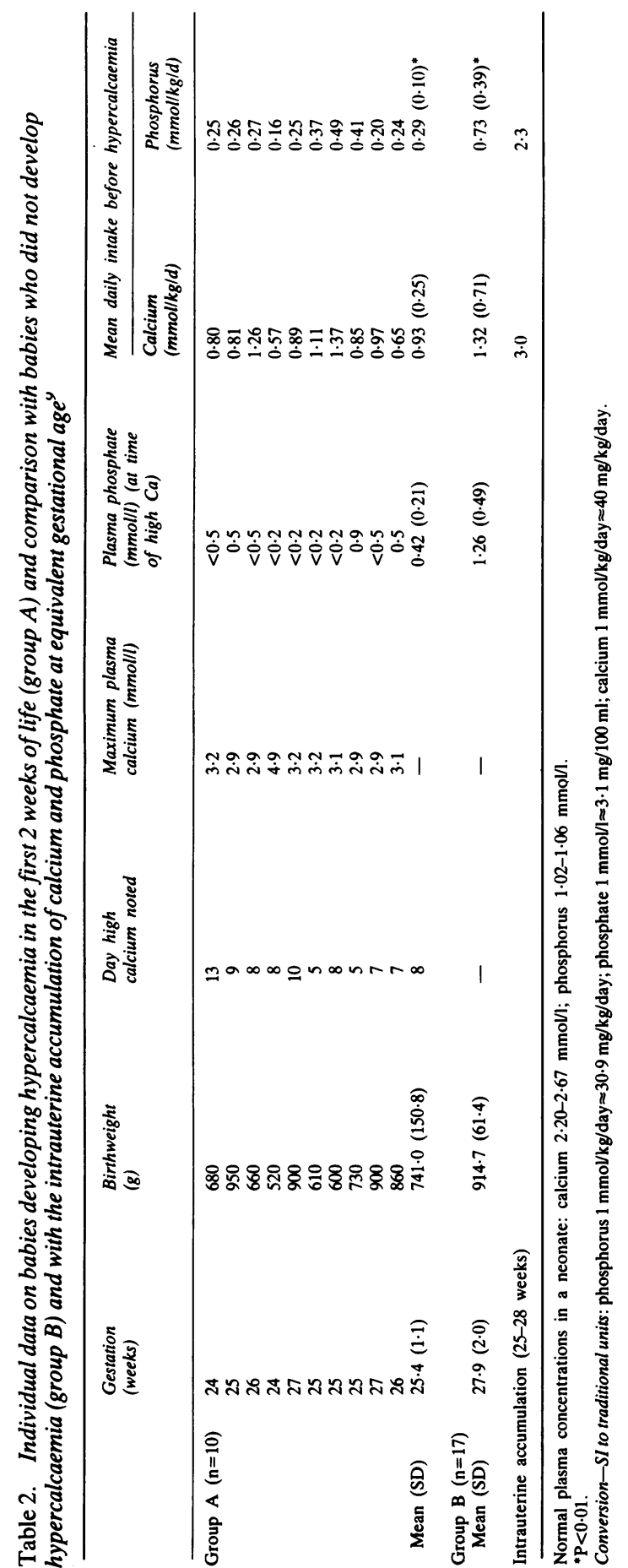

calcium concentration during their first two weeks of life, reaching supranormal values in all cases. Mean age at first detection of a raised plasma calcium concentration was 8 days (range 5 to 13 days). Table 2 gives the details of each of these infants (group A) and compares them with the remaining 17 infants who did not develop hypercalcaemia (group B). All infants in group A had very low plasma phosphate concentrations (mean less than $0.5 \mathrm{mmol} / \mathrm{l}(1.5$ $\mathrm{mg} / 100 \mathrm{ml})$, range less than 0.2 to $0.9 \mathrm{mmol} / 1(0.6$ to $2.7 \mathrm{mg} / 100 \mathrm{ml}$ )) at the time of diagnosis of hypercalcaemia. In group $B$ the mean plasma phosphate value in the first two weeks of life was $1.26 \mathrm{mmol} / \mathrm{l}(3.9 \mathrm{mg} / 100 \mathrm{ml})$ range 0.6 to $2.0(1.8$ to $6.2 \mathrm{mg} / 100 \mathrm{ml}))(\mathrm{P}<0 \cdot 0001)$.

Table 2 also shows the daily calcium and phosphorus intakes before the recognition of hypercalcaemia in group $\mathrm{A}$ in comparison with those of the infants with normal plasma calcium concentrations (group B), and with the likely intrauterine accumulation rate at a similar gestational age. ${ }^{9}$ There was no correlation between calcium intake and maximum calcium concentration. Phosphate intake was significantly lower in the infants in group $A$ $(\mathrm{P}<0 \cdot 01)$.

In six of the 10 infants in group $A$ the calcium intake was reduced in an attempt to correct the hypercalcaemia. Fig. 1 shows the effect of this
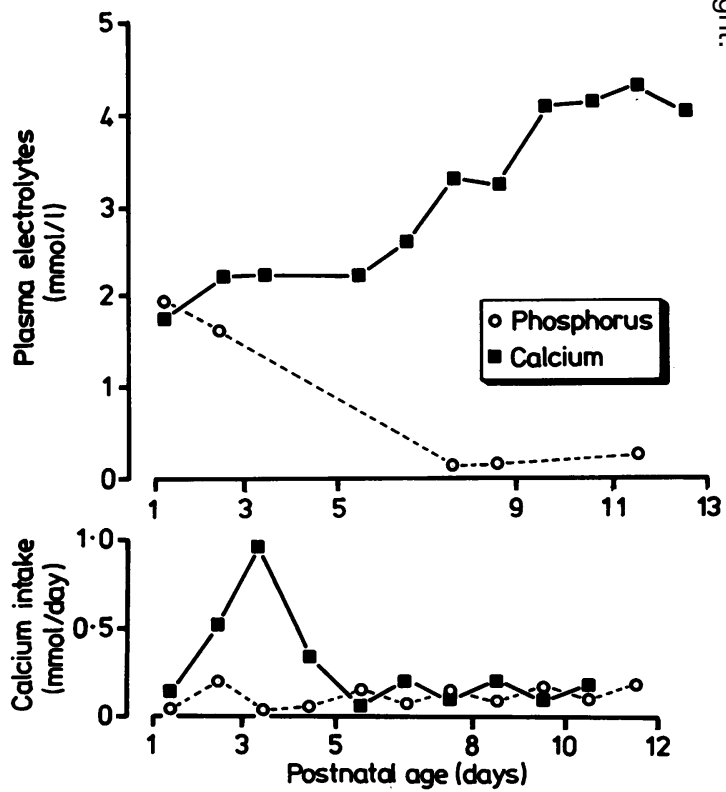

Fig. 1. Effect of reducing calcium intake on plasma calcium and phosphorus in a girl of birthweight $550 \mathrm{~g}$ and gestational age 24 weeks.

Conversion-SI to traditional units: phosphorus $1 \mathrm{mmol} / \approx 3.1 \mathrm{mg} / 100 \mathrm{ml}$; calcium $1 \mathrm{mmol} / \mathrm{l} \approx 4 \mathrm{mg} / 100 \mathrm{ml}$. 
Table 3 Mean plasma calcium and phosphate concentrations immediately before and after an increase in phosphorus intake in 10 extremely low birthweight infants with hypercalcaemia. Values mean (SD)

\begin{tabular}{|c|c|c|c|c|}
\hline & \multicolumn{2}{|c|}{ Daily intake $(\mathrm{mmol} / \mathrm{kg} / \mathrm{d})$} & \multicolumn{2}{|c|}{ Plasma concentration (mmolll) } \\
\hline & Calcium & Phosphorus* & Calcium* & Phosphorus* \\
\hline $\begin{array}{l}\text { Before } \\
\text { After additional phosphorus }\end{array}$ & $\begin{array}{l}0.93(0.25) \\
1.10(0.28)\end{array}$ & $\begin{array}{l}0.29(0.10) \\
0.96(0.31)\end{array}$ & $\begin{array}{l}3.23(0.57) \\
1.89(0.25)\end{array}$ & $\begin{array}{l}0.42(0.21) \\
1.30(0.25)\end{array}$ \\
\hline
\end{tabular}

${ }^{*} \mathrm{P}<0.001$.

Conversion-SI to traditional units: phosphorus $1 \mathrm{mmoV} / \mathrm{kg} / \mathrm{day} \approx 30.9 \mathrm{mg} / \mathrm{kg} /$ day; calcium $1 \mathrm{mmoV} \approx 4 \mathrm{mg} / 100 \mathrm{ml}$

reduction in calcium intake in one infant. In none of the infants did this prevent a continuing increase in the plasma calcium concentration.

Table 3 shows the changes in serum calcium and phosphate after an increase in phosphorus intake in the infants in group A. In the baby in whom urinary concentrations of calcium and phosphate were measured, there was a noticeable reduction in urinary calcium losses after an increase in phosphorus intake (Fig. 2).
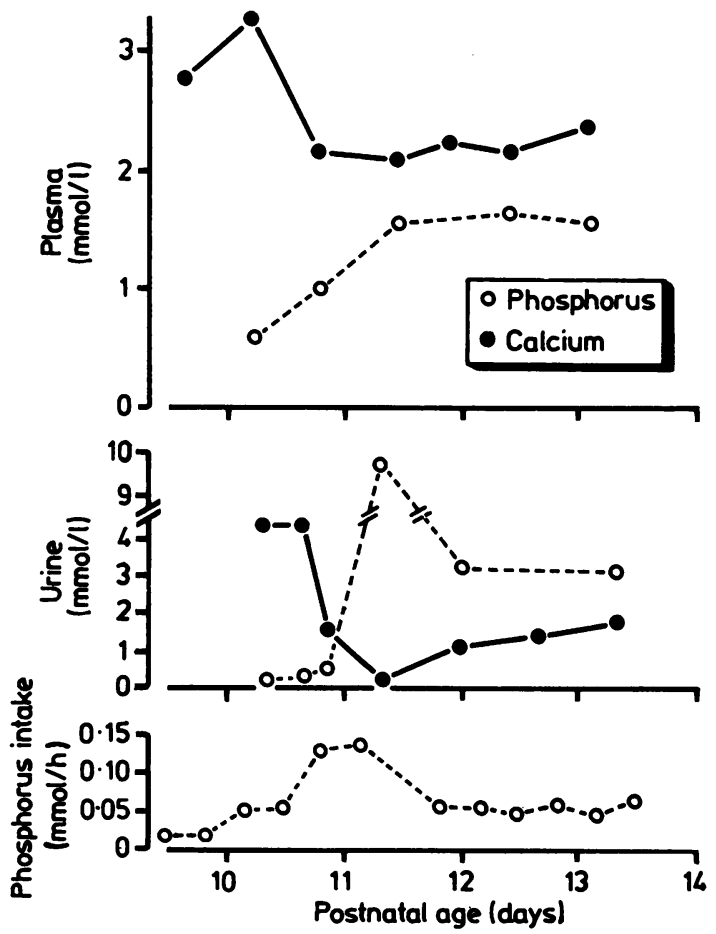

Fig. 2. Effect of increasing phosphorus intake on plasma and urinary calcium and plasma and urinary phosphate in a boy of birthweight $610 \mathrm{~g}$ and gestational age 25 weeks.

Conversion-SI to traditional units: phosphorus $1 \mathrm{mmol} / \approx 3.1 \mathrm{mg} / 100 \mathrm{ml}$; calcium $1 \mathrm{mmol} / \mathrm{l} \approx 4 \mathrm{mg} / 100 \mathrm{ml}$
In group $A$, seven of the eight infants surviving more than 28 days developed radiological evidence of rickets. Thirteen of the 17 infants in group B had wrist radiographs, 11 of these also showed evidence of rickets.

\section{Discussion}

Hypercalcaemia in the first two weeks of life has not previously been recorded as a problem in preterm neonates, and in the infants reported here it occurred only in the very immature. We suggest it is related to hypophosphataemia secondary to a low phosphorus intake, as the plasma calcium concentration was not affected by reducing the calcium intake but rapidly became normal on increasing phosphorus in the diet. The phosphorus intake was very much less in these infants than the probable intrauterine accumulation rate, ${ }^{9}$ and significantly lower than in those infants who did not develop hypercalcaemia.

The reduction in calciuria at the same time as the decrease in the plasma calcium concentration suggests that the effect of the increased phosphorus intake was to deposit calcium phosphate in bone. Senterre $e t a^{10}$ have shown in preterm infants an increase in calcium retention, due to a decrease in calciuria when phosphate supplements were added to expressed breast milk. We suggest that the initial hypercalcaemia in the presence of hypophosphataemia was due to the mobilisation of calcium and phosphorus from bone as the infant attempted to maintain an adequate plasma phosphate concentration for its essential role in soft tissue maintenance and growth.

A similar phosphorus depletion syndrome has been described in adults ${ }^{11}$ and is characterised by hypophosphataemia, hypophosphaturia, increased gastrointestinal absorption of calcium, hypercalciuria, and increased resorption of skeletal calcium and phosphorus with debility. Severe hypercalcaemia caused by phosphorus depletion has not been described in man, although it occurs in laboratory animals, ${ }^{12}$ and its occurrence in the 
extremely low birthweight infant probably reflects the immaturity of the renal function of these babies.

During the second week of life the infants of birthweight less than $1000 \mathrm{~g}$ had a mean weight gain of $15 \mathrm{~g} / \mathrm{kg} / \mathrm{day}$, with no difference between the group developing hypercalcaemia and those with normal calcium concentrations. This weight gain is close to the calculated intrauterine growth rate at a similar gestational age. ${ }^{13}$ It is easy to speculate that during this period of rapid growth, the low calcium and phosphorus intake may result in problems in ossification. We suggest, however, that there is not just a failure of postnatal mineralisation but, in the early weeks of life, an active demineralisation of bone which takes place as the infants attempt to maintain their plasma phosphate concentrations in the presence of very low phosphate intakes.

Compared with infants with normal calcium concentrations, the group with hypercalcaemia were less mature, of lower birthweight, and required more parenteral nutrition. They had a significantly lower intake of phosphate than expected from the normal feeding policy on the unit. This group of infants would have been more likely to be fluid restricted (and, therefore, because of the use of standard feeding srlutions, mineral restricted) because of problems of prematurity, in particular patent ductus arteriosus. In addition, during the first two weeks of life, the lipid infusion, solution II, with its high phosphate content would often be omitted because of jaundice, although the extent to which the phosphorus in phospholipid can be freely exchanged with the rest of the body pool of phosphorus is not known.

One consideration is whether the high dosage of vitamin D prescribed (2000 U/day) may have contributed to the hypercalcaemia. We feel this is unlikely for two reasons. Firstly, the hypercalcaemia occurred in four babies before the vitamin $D$ was introduced and secondly the problem was not seen in bigger babies more able to tolerate enteral feeds of milk and vitamin D.

Standard solutions of parenteral nutrition fluid, prepared under aseptic conditions in pharmacy, have several advantages, particularly in reducing infection and possible prescription errors. If, however, standard solutions are to be used, the resultant reduced mineral and caloric intakes must be considered when fluid restriction is applied.

The optimal intake of calcium and phosphorus in the very low birthweight neonate is not known, although infants fed formula preparations do not develop such low plasma phosphate concentrations. ${ }^{8}$ The infants in group $\mathrm{B}$ with normal calcium concentrations had a similar incidence of rickets to group A who developed hypercalcaemia, suggesting that an intake of approximately $1 \mathrm{mmol} /$ $\mathrm{kg}$ /day of calcium and phosphorus, although preventing significant plasma abnormalities, is still insufficient.

In view of our ability to obtain weight gains similar to those in utero in these extremely low birthweight infants, it may also be more logical to try and achieve intakes of calcium and phosphate that are nearer to those of the fetus.

We thank the nursing and medical staff on the Neonatal Unit for their care of these small infants and Mrs S Garrett and Mrs V Williams for their secretarial help.

\section{References}

' Bosley ARJ, Verrier-Jones ER, Campbell MJ. Aetiological factors in rickets of prematurity. Arch Dis Child 1980;55:683-6.

2 McIntosh N, Livesey A, Brooke OG. Plasma 25 hydoxy-vitamin $\mathrm{D}$ and rickets of extremely low birthweight. Arch Dis Child 1982;57:848-50.

${ }^{3}$ von Sydow C. A study of the development of rickets in premature infants. Acta Paediatrica 1946;33(suppl 2):1-22.

4 Rowe JC, Wood DH, Rowe DW, Raisz LG. Nutritional hypophosphataemic rickets in a premature infant fed on breast milk. N Engl J Med 1979;300:292-6.

${ }^{5}$ Sagy M, Birenbaum E, Baln A, et al. Phosphate depletion syndrome in a premature infant fed human milk. $J$ Pediat 1980;96:683-5.

6 Steichen JJ, Grattan TL, Tsang RC. Osteopenia of prematurity: the cause and possible treatment. J Pediatr 1980;96:528-34.

${ }^{7}$ Feeley RM, Eitenmiller RR, Jones BJ, Barnhart H. Calcium, phosphorus and magnesium contents of human milk during early lactation. Journal of Pediatric Gastroenterology and Nutrition 1983;2:262-7.

${ }^{8}$ Lyon AJ, McIntosh N. Calcium and phosphorus balance in extremely low birthweight infants in the first six weeks of life. Arch Dis Child 1984:59:1145-50.

${ }^{9}$ Widdowson EM, Dauncey JD, Shaw JCL. Trace elements in fetal and early post natal development. Proc Nutr Soc 1974;33:275-84.

10 Senterre J, Putet G, Salle B, Rigo J. Effects of vitamin D and phosphorus supplementation on calcium retention in preterm infants fed banked human milk. J Pediatr 1983;103:305-7.

$"$ Lotz M, Zisman E, Bartter FC. Evidence for a phosphorus depletion syndrome in man. $N$ Engl J Med 1968;278:409-15.

12 Baylink D, Wergedal J, Stauffer M. Formation, mineralisation and resorption of bone in hypophosphataemic rats. J Clin Invest 1971;50:2519-30.

13 Lubchenko LO, Hansman C, Dressler M, et al. Intrauterine growth as estimated from live born data at 24 to 42 weeks of gestation. Pediatrics 1963;32:793-800.

Correspondence to Dr N McIntosh, Neonatal Unit, St George's Hospital, Blackshaw Road, London SW17 OQT.

Received 20 August 1984 